\title{
REPORT ON PHYLLOPLANE MYCOFLORA ASSOCIATED WITH CATHARANTHUS ROSEUS (L.) G. DON - A HERBAL MEDICINAL PLANT IN BANGLADESH
}

\author{
Shamim Shamsi ${ }^{*}$ and Razia Sultana \\ Department of Botany, University of Dhaka, Dhaka-1000, Bangladesh
}

Catharanthus roseus (L.) G. Don is a well known, widely distributed ornamental plant and important medicinal plant also. The plant is severely attacked by fungi. In a recent study an attempt was made to find out the association of fungi with $C$. roseus which revealed the presence of seven species of Dematiaceous fungi associated with the infected leaves. The isolated fungi were Alternaria alternata ( Fr.) Keissler, Alternaria sp., Arthrinium saccharicola Stevenson, Aspergillus flavus Link., Curvularia brachyspora Boedijn, Curvularia eragrostidis (P. Henn.) J.A. Meyer and a species of Monilia Pers.

Catharanthus roseus (L.) G. Don (Madagascar Periwinkle) is a species of Catharanthus native and endemic to Madagascar. Synonyms include Vinca rosea (the basionym), Ammocallis rosea, and Lochnera rosea. It is cited (under its synonym Vinca rosea) in the Louisiana State Act 159. Other English names occasionally used include Cape Periwinkle, Rose Periwinkle, Rosy Periwinkle and old-maid. This plant belongs to family Apocynaceae. Gardeners and herbalists cultivated vinca for centuries in Europe, India, China, and America (Huxley 1992).

Traditionally, the plant has been used for relieving muscle pain, depression of the central nervous system and wasps stings. It is used in the cases of nose bleed, bleeding gums, mouth ulcers and sore throats. It has also been used internally for the treatment of the loss of memory, hypertension, cystitis, gastritis, enteritis, diarrhoea and the raised blood sugar levels. Its application ranges widely from the prevention of cancer, cancer treatment, anti-diabetic, stomachic etc. Catharanthus roseus was the highly exploited and studied medicinal plants as it was found to produce more than 100 monoterpenoid indole alkaloids (MIAs) that includes the two major commercially important cytotoxic dimeric alkaloids that are used in the cancer chemotherapy. Catharanthus roseus was also found to be a good source of the non-enzymatic and enzymatic antioxidants. From the traditional period itself, the plant has been used to cure diabetes and high blood pressure as it was believed to promote the insulin production or to increase the body's usage of the sugars from the food in case of diabetes (Gajalakshami et al. 2013).

Catharanthus plants mostly suffers from root rot, Botrytis grey mould, alternaria leaf

*Corresponding author: < prof.shamsi@gmail.com> 
spot, and aerial phytophthora diseases, the latter is the most common fungus causing damage of the plants (Wikipedia 2014). Considerable research work has been done on alkaloids and medicinal values of the plant and its fungal diseases throughout the world. In Bangladesh it is a popular garden plant but their is no report regarding its fungal diseases (Ahmed et al. 2008, Yusuf et. al. 2009 and Gani 2003).

Most of the member of deuteromycetes are associated with angiospermic plants as endophytes, saprophytes or parasites. To protect the important plants from fungal attack it is a routine work for mycologists and plant pathologists to know the identity of the fungi. Keeping this in mind present research was undertaken to find out the association of fungi and their identity with the said plant.

Infected twig with superficial black mycelial growth of fungi were collected from Dhaka city during the period of April, 2008 to July, 2009 (Fig. 1. A-D). The experiment was carried out in the laboratory of Mycology and Plant Pathology, Department of Botany, University of Dhaka. Twenty samples were examined from infected leaves of Chatharanthus plants. The fungi were isolated on PDA (Potato Dextrose Agar) medium following "Tissue planting method" (Tuite 1969). Percentage association of the fungi was also recorded.

Identification of the isolates were determined following the standard literatures (Ellis 1971,1976 and Ellis and Ellis 1997).

Pathogenecity of the isolated fungi was done following detached leaf technique (Azad and Shamsi 2011).

Present investigation revealed the presence of seven species of Dematiaceous Hyphomycetes associated with infected leaves. The isolated fungi were Alternaria alternata, Alternaria sp., Arthrinium saccharicola, Aspergillus flavus, Curvularia brachyspora, C. eragrostidis and Monilia sp. Frequency percentage of association of Alternaria spp. was higher (37.7) and A. saccharicola was lower (2.2) (Table 1).

Table 1. Frequency (\%) of association of fungi with Catharanthus roseus.

\begin{tabular}{lc}
\hline Name of fungi & \% of fungi \\
\hline Alternaria alternatea & 11.1 \\
Alternaria sp. & 26.6 \\
Arthrinium saccharicola & 2.2 \\
Aspergillus flavus & 8.9 \\
Curvularia brachyspora & 13.3 \\
Curvularia eragrostidis & 13.3 \\
Monilia sp. & 17.8
\end{tabular}




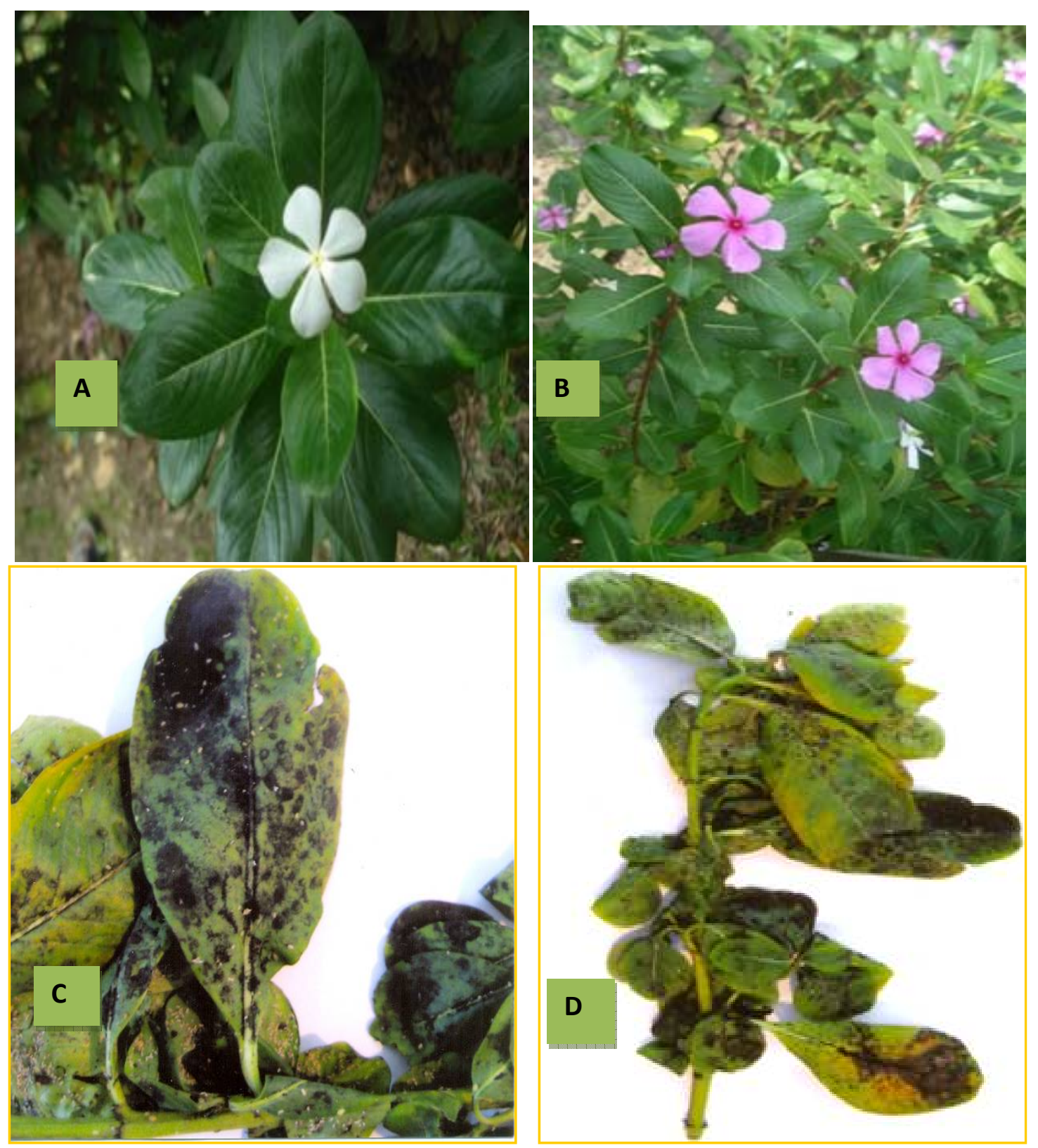

Fig. 1. Catharanthus roseus: Healthy plants (A- B), infected twigs (C- D). 


\section{Description of the fungi associated with $C$. roseus}

\section{Alternaria alternata (Fr.) Keissler (Fig. 2. A)}

Colony black to olivaceous-black on PDA medium. Mycelia brown, septate, branched. Conidiophores brown, short or elongate, 17 - 65 (76) $\mu \mathrm{m}$ long and 8 - $12 \mu \mathrm{m}$ in width. Conidia obclavate, obpyriform, sometimes ovoid or ellipsoidal, often with a short conical or cylindrical beak, pale brown, smooth or verrucose, 3 - 5 transverse septate and 0 - 4 longitudinal or oblique septate, $30-67$ (76 ) $\times 9-20 \mu \mathrm{m}$ in the broadest part. Beak pale, 2, 4 - $5 \mu$ m thick.

The genus contains 44 species of which most are plant parasites, but a few species are ubiquitous and are also frequently soil-borne. Alternaria alternata is the commonest of these. Although usually seen as saprophytic contaminants.

Alternaria sp. (Fig. 2. B)

Colony grayish black. Mycelia brown, septate, branched, partly superficial partly immersed. Conidiophores brown, short or elongate arising singly from hyphae, 12 - 68 $\mu \mathrm{m}$ long and 7 - $11 \mu \mathrm{m}$ in width. Conidia obclavate, obpyriform, sometimes ovoid or ellipsoidal, often with a short conical or cylindrical beak, pale brown, smooth 52 - 83 (55) $\times 15$ - $26 \mu \mathrm{m}$ in the broadest part. Beck pale, 4 - $10 \mu \mathrm{m}$ thick.

Arthrinium saccharicola Stevenson (Fig. 2. C)

Colonies whitish with black spore mass, mycelia brown, septate, branched. Conidiophores short, brown. $2-4 \mu \mathrm{m}$, conidia, grown, sub circular to circular or ellipsoidal, smooth, sometimes with median slit, 7.1 - $9.4 \mu \mathrm{m}$.

The fungus is mostly saprophytic, isolated from sugarcane. Mostly saprophytic in nature.

Aspergillus flavus Link. (Fig. 2. D)

Colony yellowish green, spreading rapidly on PDA medium. Conidiophores deep brown, arising from submerged hyphae, 450 to $970 \mu \mathrm{m}$ long, 6-15 $\mu \mathrm{m}$ diameter. Vesicles 10 to 30 or $40 \mu \mathrm{m}$ diameter.

Primary sterigmata $7-10 \times 3-4 \mu \mathrm{m}$, secondary sterigmata $7-10 \times 2.5-3 \mu \mathrm{m}$. Conidia pale green, pyriform to almost globose, $3-4 \times 4-5 \mu \mathrm{m}$.

It is mostly saprotrophic but sometimes pathogenic fungus with a cosmopolitan distribution. It is best known for its colonisation of cereal grains and legumes. Post-harvest rot typically develops during harvest, storage, and/or transit. 


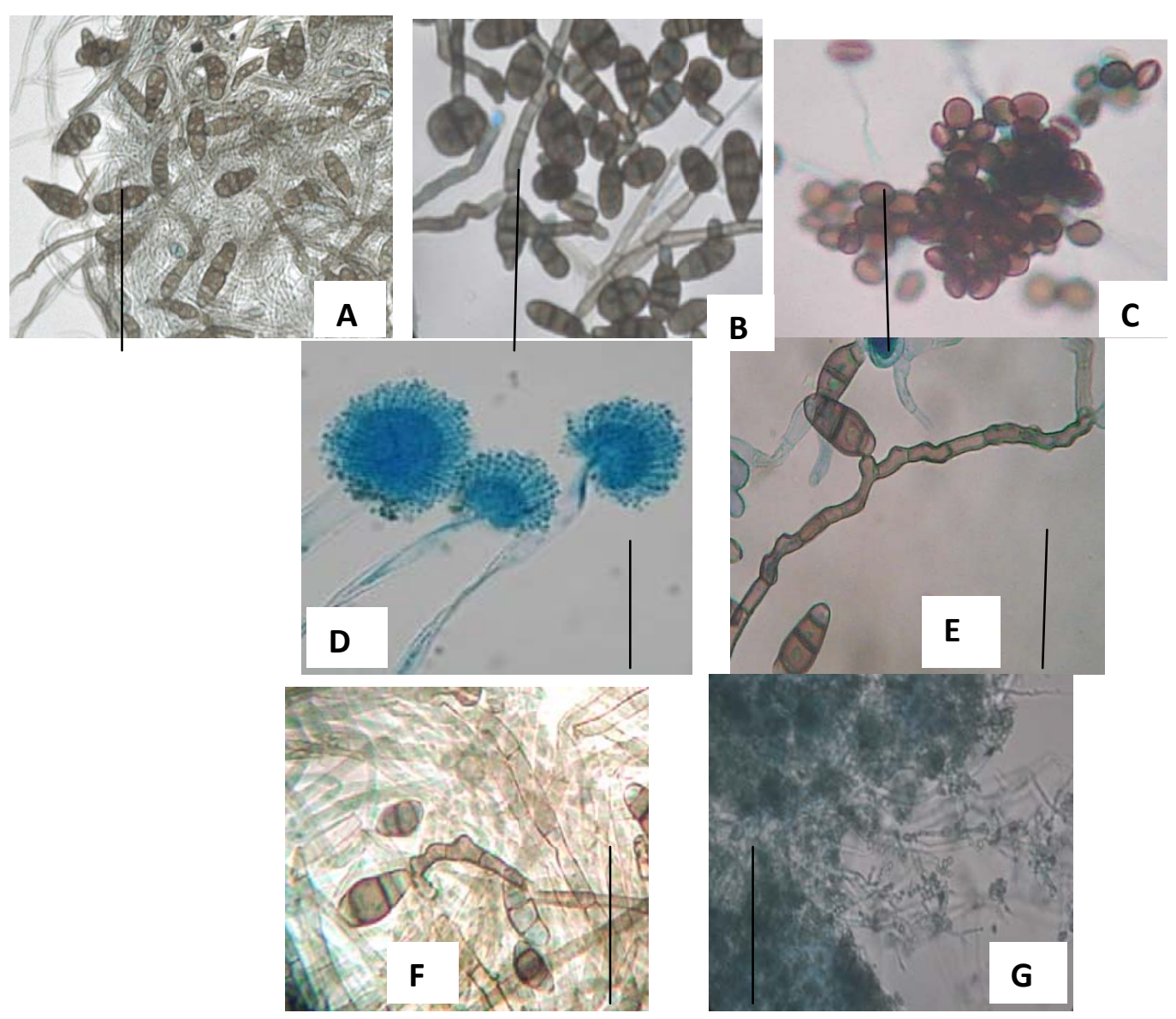

Fig. 2. Conidiophores and conidia of Alternaria alternata (A), Alternaria sp. (B), Arthrinium saccharicola (C), Aspergillus flavus (D), Curvularia brachys-pora (E), C. eragrostidis (F) and Monilia sp. $(\mathrm{G})((\mathrm{Bar}=50 \mu \mathrm{m})$.

\section{Curvularia brachyspora Boedijn (Fig. 2. E)}

Colony effuse grayish black. Conidiophores brown, solitary, mostly unbranched, slightly geniculate, up to $140 \mu \mathrm{m}$ long, 5 - $8 \mu \mathrm{m}$ width. Conidia dark brown, straight or slightly curved, Third cell from the base broadest and darker than other, smooth. 18 - 24 $\times 9-14 \mu \mathrm{m}$.

\section{Curvularia eragrostidis (P. Henn.) J.A. Meyer (Fig. 2. F)}

Colony effuse grayish black. Conidiophores brown, solitary, mostly unbranched, slightly flexuous, up to $80 \mu \mathrm{m}$ long, $5-8 \mu \mathrm{m}$ width. Conidia dark brown, straight or slightly curved, third cell from the base broadestand darker than other, smooth. $24-37 \times$ $10-18 \mu \mathrm{m}$. 
Colony effuse grayish black. Conidiophores brown, solitary, mostly unbranched, slightly geniculate, up to $140 \mu \mathrm{m}$ long, 5 - $8 \mu \mathrm{m}$ width. Conidia dark brown, straight or slightly curved, Third cell from the base broadest and darker than other, smooth. 18 - 24 $\times 9-14 \mu \mathrm{m}$.

\section{Curvularia eragrostidis (P. Henn.) J.A. Meyer (Fig. 2. F)}

Colony effuse grayish black. Conidiophores brown, solitary, mostly unbranched, slightly flexuous, up to $80 \mu \mathrm{m}$ long, 5 - $8 \mu \mathrm{m}$ width. Conidia dark brown, straight or slightly curved, third cell from the base broadestand darker than other, smooth. $24-37 \times$ $10-18 \mu \mathrm{m}$.

Monilia Pers. (Fig. 2. G)

Colony transparent, effuse very fast growing with pink conidial mass on PDA medium. Mycelia pale olevaceous brown, septate, branched, 3 - $4 \mu$ midth. Phialides 32.4 - $68.4(97.2) \times 2.7$ - $4.5 \mu \mathrm{m}$. Conidia greenish, aseptate, ellipsoidal, catenulate, 6 $9.2 \times 3.8-4.6 \mu \mathrm{m}$.

So far, root rot, Botrytis grey mould, Alternaria leaf spot, and aerial Phytophthora diseases of Catharanthus has been reported, the latter is the most common fungus causing damage of the plants (Wikipedia 2014).

Pathogenicity test of the fungi following detached leaf technique revealed that isolated fungi were non pathogenic to $C$. roseus. So the associated fungi are saprophytic in nature. In the saprophytic form the fungi are also destructive to the plant. They destroy the cells of the plant, reduce photosynthetic area of the infected plant as well as decrease the quality and quantity of the produce.

The present report is the first record of association of Arthrinium saccharicola, Aspergillus flavus, Curvularia brachyspora, C. eragrostidis and Monilia sp. with Catharanthus plant. Present investigation will be helpfull for designing fungal disease management of the plant.

\section{References}

Ahmed, Z. U., Begum Z.N.T., Hassan, M.A., Khondker, M., Kabir, S. M. H., Ahmed, M. Ahmed, A.T.A., Rahman, A.K.A., Haque, E.U. 2008. Encyclopedia of Flora and Fauna of Bangladesh. Angiosperms:Dycotyledons (Apocynaceae-Asteraceae). Asiatic Society of Bangldesh. Dhaka 6:178-179.

Azad, R. and S. Shamsi. 2011. Identification and pathogenic potentiality of fungi associated with Huttuyania cordata Thunb. Dhaka Univ. J. Biol. Sci. 20:(2): 131-138.

Ellis, M. B. 1971. Dematiaceous Hyphomycetes. Commonwealth Mycological Institute, England, pp. 608 
Ellis, M.B.1976. More Dematiaceous Hyphomycetes. Commonwealth Mycological Institute, England. pp. 507.

Ellis MB, JP Ellis 1997. Micro fungi on Land plants. An Identification Handbook. The Richmond Publishing Company Ltd. pp. 868.

Gajlalakshmi, S., S.Vijayalakshmi and R. V. Devi. 2013. Pharmacological activities of Catharanthus roseus. J. Pharm. Bio. Sci. 4(2): 431- 439.

Gani, A . 2003. Medicinal Plants of Bangladesh : Chemical constituents and uses. Asiatic Society of Bangladesh. pp. 603.

Huxley, A. 1992. New RHS Dictionary of Gardening. Macmillan ISBN 0-333-47494-5.

Tuite, J. 1969. Plant Pathological methods. Fungi and Bacteria. Burgess Publishing Company. Minneapolis, Minnesota. USA. pp. 239.

Yusuf, M., J. Begum, M. N. Haque and S. U. Chawdhury. 2009. Medicinal Plants of Bangladesh. Bangladesh Council of Scientific and Industrial Research Laboratories Chittagong. Chittagong-4220. Bangladesh. pp. 794.

Wikkipedia. 2014. Catharanthus roseus. The free Encyclopedia.

(Manuscript received on 29 June 2014; revised on 20 August, 2014) 